\title{
Screening and Quantification of Antiquorum- Sensing Activity of Actinobacteria Isolates Against Gram-Positive and Gram-Negative Biofilm Associated Bacteria
}

\section{Marco Wijaya}

Universitas Katolik Indonesia Atma Jaya

Dea Delicia

Universitas Katolik Indonesia Atma Jaya

Diana Elizabeth Waturangi ( $\nabla$ diana.waturangi@atmajaya.ac.id )

Universitas Katolik Indonesia Atma Jaya

\section{Research note}

Keywords: Actinobacteria, Antibiofilm, Chromobacterium violaceum , Quorum sensing, Quorum quenching

Posted Date: February 25th, 2020

DOl: https://doi.org/10.21203/rs.2.24412/v1

License: (c) (1) This work is licensed under a Creative Commons Attribution 4.0 International License.

Read Full License 


\section{Abstract}

Objectives: The purpose of the study is to screen antiquorum sensing activity compound from actinobacteria using Chromobacterium violaceum as indicator and quantify the antibiofilm activity against several biofilm-forming pathogenic bacteria, such as Staphylococcus aureus ATCC 29213, Bacillus cereus ATCC 14579, Enterococcus faecalis ATCC 33186, Vibrio cholerae, Salmonella typhimurium , Pseudomonas aeruginosa ATCC 27853.

Results: Crude extracts from marine actinobacteria isolated from Indonesia were promising for treating biofilm-related diseases. Out of 40 isolates 10 were found to have great quorum quenching activity against $\mathrm{C}$. violaceum. Moreover, these isolates were able to inhibit biofim formation by Gram positive and Gram negative pathogenic bacteria. Quorum quenching agents in extracts of 1AC, 14PM, 16PM, 18PM, and CW17 isolates were predicted as proteins or enzymes.

\section{Introduction}

Bacteria can communicate with each other using unique chemical compounds called autoinducer. Communication activity of bacteria is known as quorum sensing. This mechanism is referring to the capacity of bacteria to monitor their cell density. Quorum sensing also affects the genes expression which influences microbial behaviors, such as regulating virulence factors and biofilm formation $\left[{ }^{1}, 2\right]$.

Biofilm formation is a process when flocked bacteria develop extracellular matrix that facilitate attachment. It gives rise to serious problems for public health because biofilm-associated organisms are more resistant to chemical agents and physical treatments. In this case, the probability of successful infections will increase [2]. Every activity to inhibit bacterial quorum sensing is known as quorum quenching. It has been proposed as novel therapeutics for treating biofilm-based diseases.

The biofilm-based diseases are usually treated by antibiotics. However, the use of antibiotics is not an effective solution and might lead to antibiotic resistance. Actinobacteria are fungi-like Gram-positive bacteria, well known as a supreme producer of secondary metabolite compounds [ $\left.{ }^{3}\right]$, but research around antiquorum sensing and antibiofilm from these bacteria yet have not been much explored. The objectives of this research are to screen antiquorum sensing activity compound from actinobacteria using $\mathrm{C}$. violaceum as indicator and quantify the antibiofilm activity against several biofilm-forming pathogenic bacteria.

\section{Methods}

\section{Bacterial Cultivation}

Fourty actinobacteria isolates used in this research were obtained from the previous study $[4,5]$ that isolated from aquatic environments in Indonesia. Actinobacteria were cultured onto Yeast Malt Extract Agar (YMEA) incubated at $28^{\circ} \mathrm{C}$ for 7 days. Indicator strains of quorum sensing activity were $C$. violaceum 
wild type and C. violaceum CV026 cultivated onto Luria Agar (LA) and incubated at $28^{\circ} \mathrm{C}$ for $24 \mathrm{~h}$. While six pathogenic bacteria which were B. cereus ATCC 14579, S. aureus ATCC 29213, and E. faecalis ATCC $33186, P$. aeruginosa ATCC 27853, S. typhimurium, $V$. cholerae cultivated onto LA and incubated at $37^{\circ} \mathrm{C}$ for $24 \mathrm{~h}$.

\section{Primary Screening of Antiquorum Sensing Activity}

The assay was conducted using the overlay agar method [6] with modification. Actinobacteria isolates were inoculated into YMEA then incubated at $28^{\circ} \mathrm{C}$ for 3 days. C. violaceum were grown separately in Luria Broth (LB) and incubated at $28^{\circ} \mathrm{C}$ for $24 \mathrm{~h}$. The indicator strain diluted within semisolid agar $(0.75 \%$ $\mathrm{LA}$ ) until $\mathrm{OD}_{600}=0.132$ and poured onto YMEA plates. These plates were incubated at $28^{\circ} \mathrm{C}$ for $24 \mathrm{~h}$. Positive result indicating antiquorum sensing can be seen through the absence of violacein pigment production around actinobacteria isolates.

\section{Preparation of Crude Extract}

Each isolate was inoculated into Tryptic Soy Broth (TSB) supplemented with glucose $(1 \% \mathrm{w} / \mathrm{v})$. The culture was incubated at $28^{\circ} \mathrm{C}$ for 7 days at $125 \mathrm{rpm}$ then centrifuged at $7,800 \mathrm{xg}$ for 15 minutes. The supernatant was mixed with ethyl acetate in a 1:1 ratio and shaken at $150 \mathrm{rpm}$ overnight. The solvent phase was evaporated using rotary evaporator then dried using vacuum oven and resuspended in Dimethyl Sulphoxide (DMSO). Crude extracts were stored at $-20^{\circ} \mathrm{C}$ for a month $[7,8,9]$

\section{Antimicrobial Assay}

Assay is conducted using agar well diffusion method [10]. Tested bacteria $\left(\mathrm{OD}_{600}=0.132\right)$ were streaked onto Brain Heart Infusion Agar (BHIA). The crude extract $(50 \mu \mathrm{L})$ of actinobacteria with various concentration (10 and $20 \mathrm{mg} / \mathrm{mL}$ ) was added. DMSO (1\% v/v) was used as the negative control, while streptomycin $(10 \mathrm{mg} / \mathrm{mL})$ was used as the positive control. The plates were incubated at $37^{\circ} \mathrm{C}$ for $24 \mathrm{~h}$.

\section{Detection of Antiquorum Sensing Activity}

This assay was conducted based on [11] with modification. $C$. violaceum $\left(\mathrm{OD}_{600}=0.132\right)$ used as indicator strain streaked onto BHIA. The crude extract $(50 \mu \mathrm{L})$ of actinobacteria with various concentration (10 and $20 \mathrm{mg} / \mathrm{mL})$ was added. DMSO ( $1 \% \mathrm{v} / \mathrm{v})$ was used as a control. The plates were incubated at $28^{\circ} \mathrm{C}$ for $24 \mathrm{~h}$. Antiquorum sensing activity was determined qualitatively through the inhibition of violacein production around the wells [12]

\section{Quantification of Antibiofilm Activity}

Quantification of antibiofilm activity was conducted based [8] with modification. The antibiofilm activity was divided into inhibition and destruction activity. For inhibition activity assay, each pathogen was inoculated into Brain Heart Infusion Broth (BHIB) supplemented with glucose $(2 \% \mathrm{w} / \mathrm{v})$ and incubated at $37^{\circ} \mathrm{C}, 150 \mathrm{rpm}$ for $24 \mathrm{~h}$. Then $100 \mu \mathrm{L}$ of bacterial culture $\left(\mathrm{OD}_{600}=0.132\right)$ and $100 \mu \mathrm{L}$ of crude extract was 
transferred to the 96-wells microplate to quantify the biofilm inhibition activity. For destruction activity assay, another 96-wells plate was filled with diluted culture and re-incubated at $37^{\circ} \mathrm{C}$ for $24 \mathrm{~h}$ until mature biofilm attached to the well. Crude extract $(100 \mu \mathrm{L})$ was added to each well to quantify the biofilm destruction activity. Overnight culture of pathogens without any treatment was used as a positive control, while sterile BHIB was used as the negative control.

After incubation, planktonic cells and media were discarded. Adherent cells were rinsed twice with sterile water and stained using crystal violet $(0.4 \% \mathrm{w} / \mathrm{v})$ for 30 minutes. 96 -wells were rinsed twice and air-dried for 5 minutes. About $200 \mu \mathrm{L}$ of ethanol was added and resuspended. Absorbance was determined at 595 $\mathrm{nm}$ with a microplate reader (TECAN M200 PRO). This assay was performed in triplicates. Percentage of inhibition or destruction activity was calculated by the equation below:

$\%$ Activity $=\frac{\text { OD Control }- \text { OD Treated }}{\text { OD Control }} \times 100 \%$

\section{Validation of Quorum sensing inhibition}

Validation assay was conducted based on [11]. The culture of $C$. violaceum $\mathrm{CV} 026\left(\mathrm{OD}_{600}=0.132\right)$ was mixed with $100 \mu \mathrm{L}$ of the crude extract and $1 \mu \mathrm{mol} / \mathrm{mL}$ of Hexanoyl-L-Homoserine-Lactone (HHL). The culture was incubated at $28^{\circ} \mathrm{C}$ for $24 \mathrm{~h}$. Positive control contained culture and $1 \mu \mathrm{mol} / \mathrm{mL}$ of $\mathrm{HHL}$ without crude extract. The tested tubes were centrifuged at 1000rpm for 15 minutes. About $1 \mathrm{~mL}$ of DMSO (1\% $\mathrm{v} / \mathrm{v}$ ) mixed and centrifuged. The absorbance of the supernatant was measured at $540 \mathrm{~nm}$. Furthermore, the determination of protein compounds in the crude extract was performed. Each crude extract was treated with proteinase $-\mathrm{K}(100 \mu \mathrm{g} / \mathrm{mL})$ for $2 \mathrm{~h}$ incubation in $37^{\circ} \mathrm{C}$ and heat loss method with $95^{\circ} \mathrm{C}$ for $1 \mathrm{~h}$. The treated crude extract was used to do the validation assay. Total violacein produced by $C$. violaceum CV026 was compared [13]

\section{Examination of Biofilm formation by Scanning Electron Microscope (SEM)}

The effect of crude extract was investigated using SEM at Dexa Laboratory of Biomolecular and Science (DLBS), Cikarang, Indonesia. B. cereus and S. typhimurium were grown in BHIB supplemented with glucose $(2 \% \mathrm{w} / \mathrm{v})$ and incubated at $37^{\circ} \mathrm{C}$ for $24 \mathrm{~h}$. Bacterial culture $(100 \mu \mathrm{L})$ were spotted to sterile cover glass kept in sterile petri dish and incubated at $37^{\circ} \mathrm{C}$ for $24 \mathrm{~h}$ to form a mature biofilm. After the incubation period, $100 \mu \mathrm{L}$ of crude extract with the highest destruction activity was added into the formed biofilm and incubated at $37^{\circ} \mathrm{C}$ for $24 \mathrm{~h}$. Mature biofilm without crude extract was used as control [14].

\section{Statistical Analysis}

Statistical analysis was conducted by using IBM SPSS Statistics 23 . The results were analyzed using the analysis of variances (ANOVA) and the Tukey test for significant difference were determined at $P<0.05$ and standard error was determined using Microsoft Excel 2016. 


\section{Results}

\section{Bacterial Characteristic}

Actinobacteria isolates have specific characteristics, such as calcareous-like, opaque big colonies, embedded or strongly attached to the agar medium, and produce earthy odor compounds called geosmin.

\section{Screening for Antiquorum Sensing Activity}

Inhibition of violacein pigment was determined as a positive result. According to this assay, The results showed that 10 out of $\mathbf{4 0}$ actinobacteria isolates had antiquorum sensing activity without inhibiting C.violaceum growth.

\section{Antibacterial Activity Assay}

There were found 3 out of the 10 actinobacteria crude extracts showed antibacterial activity against $V$. cholerae and non-antibacterial activity against other pathogens, while positive control inhibited the growth of tested pathogens.

\section{Detection of Antiquorum Sensing Activity}

All 10 isolates also performed great quorum quenching activity against $C$. violaceum shown with absence of violacein pigment observed around the wells. Presence of quorum quenching activity would inhibit violacein production.

\section{Validation Test Antiquorum Sensing Activity and Protein Characterization}

The results shown in Table 1 indicate that all 10 isolates showed quorum quenching activity compared with the control. Quorum quenching agents in extracts 1AC, 14PM, 16PM, 18PM, and CW17 showed a significant increase in absorbance value after Proteinase-K treatment, while extracts from 11AC, 15PM, 20PM, CW01, CW17, and TB12 showed lower absorbance value (Table 1).

\section{Biofilm Inhibition and Destruction Assay}

From this assay, all crude extracts were capable of inhibiting and destructing biofilm formation (Table 2). Antibiofilm activity performed were broad spectrum. Antibiofilm against Gram positive bacteria was correlated with the concentration while results against Gram negative bacteria was varied.

\section{Microscopic Observation using Scanning Electron Microscope}

Figure $1 \mathrm{a}$ and $1 \mathrm{~b}$ showed the topographical biofilm formation of $B$. cereus before and after treated with crude extract of 20PM isolate. While Figure $1 \mathrm{c}$ and $1 \mathrm{~d}$ showed biofilm of $S$. typhimurium. Drastic morphological change observed after treatment of actinobacteria crude extract. 


\section{Discussion}

Actinobacteria live in an environment that leads them to do some kind of competitions for combating other microorganisms in various situations. Actinobacteria produce several metabolites such as antimicrobial, antiquorum sensing, antibiofilm, and several other supporting compounds.

From the first screening of antiquorum sensing activity, only 10 out of 40 actinobacteria isolates showed antiquorum sensing activity. Screening of antimicrobial activity is needed because it might lead to falsepositive result in further assays. There was no clear zone observed, except in V. cholerae. Isolates showing quorum quenching activity are validated. All 10 isolates showed great activity in inhibiting $\mathrm{C}$. violaceum quorum sensing activity as seen from lower pigment production.

Quorum quenching agents in extracts of 1AC, 14PM, 16PM, 18PM, and CW17 isolates were predicted as proteins or enzymes because they showed a significant increase in absorbance value after proteinase-K treatment. The treatment might affect protein-based antiquorum sensing compounds produced by actinobacteria, such as AHL lactonase, acylase, decarboxylase, oxidoreductase, and deaminase [15]. Those enzymes were degraded by the treatment. In the absence of antiquorum sensing compounds, $\mathrm{HHL}$ (C6) signal will diffuse into bacterial cells and binds with LuxR receptor formed a protein-ligand complex. This complex will activate violacein production. The more violacein produced, the higher absorbance will be detected [16].

Crude extract from isolate 15PM, 20PM, CW01, and TB12 treated with proteinase-K showed better activity. It might indicate that proteinase-K degrades the competitive proteins which share similar receptor or degrades proteins that can inhibit the quorum quenching activity [17]. Other probabilities, the antiquorum sensing compounds were produced in inactive form hence reaction with Proteinase- $K$ will activate the antiquorum sensing compound [18].

Antibiofilm activity usually correlates with concentration, but few isolates did not show any significant difference. It might be caused by several factors. For instance, lower concentration of crude extracts might degrade all the ECM. Crude extracts might also contain some inhibitors or analog components that match competitively to the receptor. According to [19] undesirable component might affect the effectiveness of the crude extracts. Some components in the crude extracts might work antagonistically or synergistically that can decrease or increase the activity $[18,20]$.

Topographical observation using SEM showed the presence of biofilm. S. typhimurium biofilm before treated with crude extracts showed a rough surface, which means there is a presence of ECM. After the treatment, Fig. 1d showed the crude extracts contained matrix-degrading enzymes due to the depletion and erosion across the surfaces. On the other head, B. cereusshowed thick biofilm formation. Treatment with crude extract of 20PM isolate is competent to degrade ECM and Biofilm formation [21].

\section{Conclusion}


There were 10 isolates performed great quorum quenching and antibiofilm both destruction and inhibition activity against $P$. aeruginosa ATCC 27853 , S. typhimurium, $V$. cholerae, $B$. cereus ATCC 14579 , S. aureus ATCC 29213, and E. faecalis ATCC 33186. Quorum quenching compound in extracts 1AC, $14 \mathrm{PM}, 16 \mathrm{PM}, 18 \mathrm{PM}$, and CW17 were predicted as proteins. Further research is required to purify the bioactive compounds, characterize the bioactive compounds in each crude extract, and identify the potential isolates.

\section{Limitation}

This research did not comprehend the specific compound in the crude extract that competent to perform antibiofilm and antiquorum sensing activity. species of actinobacteria have not identified, characterization of crude extract limited to protein compounds, and the specific mechanism of the quorum quenching activity of each isolate did not determine.

\section{Abbreviations}

HHL: Hexanoyl-L-Homoserine-Lactone

Al: Autoinducer

AHL: Acyl Homoserine Lactone

SEM: Scanning Electron Microscope

ECM: Extracellular Matrix

\section{Declarations}

Ethics approval and consent to participate. Not applicable

Consent for publication. Not applicable

Availability of data and materials. The data of this study is available with the corresponding author up on request.

Competing interests. The authors declare that they have no competing interests

Funding. This research had funded by Ministry of Research, Technology and Higher Education of the Republic of Indonesia 2019 and Faculty of Biotecnology, Atma Jaya Catholic University of Indonesia 2019. The funder has no contribution in design, collection, writting, and interpreting data in this research.

Authors' Contribution. MW and DD: Proposal Writting, Conducted research, Data Analysis, and manuscript under advisory of DEW. DEW: Provide the materials, methods and proposal design, and bacteria used in this research. being a final investigator in this research. 
Acknowledgement. The authors thankfully acknowledge the microscopy facility that provided by the PT Dexa Laboratories of Biomolecular Sciences (DLBS)

Author details. ${ }^{1}$ Faculty of Biotechnology, Atma Jaya Catholic University of Indonesia. Jenderal Sudirman 51 Street, South Jakarta, DKI Jakarta, 12930, Indonesia.

\section{References}

1. 1. Das S, Dash HR. Microbial-biotechnology: a laboratory manual for bacterial systems. New Delhi: Springer, 2015. p203

2. Rabin N, Zheng Y, Opoku TC, Du Y, Bonsu E, Sintim HO. Biofilm formation mechanisms and targets for developing antibiofilm agents. Future Med. Chem. 2015; doi: 10.4155/FMC.15.6.

3. Li Q, Chen X, Jiang Y, Jiang C. 2016. Actinobacteria - Basics and Biotechnological Applications. doi:10.5772/61461

4. Screening of actinomycetes from marine sediments to inhibit Vibrio cholerae biofilm formation. Biotechnology, Honours [Thesis]. Jakarta (ID): Atma Jaya Catholic University of Indonesia; 2011.

5. Vidyawan V. Screening of actinomycetes from various environment sediments to inhibit biofilm formation of Vibrio cholerae. Biotechnology, Honours [Thesis]. Jakarta (ID): Atma Jaya Catholic University of Indonesia; 2013.

6. Abudoleh SM, Mahasneh AM. Anti-quorum sensing activity of substance isolated from wild berry associated bacteria. Avicenna J Medical Biotechnol. 2017;9(1):1-8.

7. Rajivgandhi G, Senthil R, Ramachandran G, Manoharan N. Antibiofilm activity of marine endophytic actinomycetes compound isolated from mangrove plant Rhizophora mucronata, Muthupet Mangrove Region, Tamil Nadu, India. J Terr Mar Res. 2018; 2(4):1-7.

8. Waturangi DE, Rahayu BS, Lalu KY, Michael, Mulyono N. Characterization of bioactive compound from actinomycetes from antibiofilm activity against Gram-negative and Gram-positive bacteria. Malays J Microbiol. 2016; doi :10.21161/mjm.80915.

9. Nithya C, Aravindraja C and Pandian SK. 2010. Bacillus pumilus of Palk Bay origin inhibits quorumsensing-mediated virulence factors in Gram-negative bacteria. Res. Microbiol. 2010; 161 293-304.

10. Nathan P, Law EJ, Murphy DF. A laboratory method for the selection of topical antimicrobial agents to treat infected burn wounds. Burn. 1978; 4.177-17.

11. Rajivgandhi G, Vijayan R, Maruthupandy M, Vaseeharan B, Manoharan N. Antibiofilm effect of Nocardiopsis GRG 1 (KT235640) compound against biofilm-forming Gram-negative bacteria on UTIs. Microbial Pathogenis. 2018; doi: 10.1016/j.micpath.2018.03.011

12. Khan MSA, Zahin M, Hasan S, Husain FM, Ahmad I. Inhibition of quorum sensing regulated bacterial functions by plant essential oils with special reference to clove oil. Lett Appl Microbiol. 2009; doi:10.1111/j.1472-765x.2009.02666.x. 
13. Thenmozhi, R. P., Nithya, J. R. \& Pandian, S. K. Antibiofilm activity of coral-associated bacteria against different clinical M serotypes of Streptococcus pyogenes. FEMS Immunol Med Microbiol. 57, 284-294 (2009).

14. Luo J, Dong B, Wang K, Cai S, Liu T, Cheng X, Lei D, Chen Y, Kong J, Chen Y. Baicalin 263 inhibits biofilm formation, attenuates the quorum sensing-controlled virulence and enhances 264 Pseudomonas aeruginosa clearance in a mouse peritoneal implant infection model. PLoS 265 ONE. 2017;12(4): e0176883.

15. Chen F, Gao Y, Chen X, Yu Z, Li X. Quorum quenching enzymes and their application in degrading signal molecules to block quorum sensing-dependent infection. Intl. J. Mol. Sci. 2013; doi:10.3990/IJMS140917477

16. Stauff DL, Bassler BL. Quorum Sensing in Chromobacterium violaceum: DNA Recognition and Gene Regulation by the CviR Receptor. J Bacteriol. 2011; doi:10.1128/jb.05125-11.

17. Omran R, Kadhem MF. Production, purification, characterization of bioactive metabolites produced from rare Actinobacteria psudonocardia Asian J Pharm Clin res. 2016; 9(3):264-272.

18. LaSarre B, Federle MJ. Exploiting quorum sensing to confuse bacterial pathogens. Microbiol Mol Biol Rev. 2013; doi:10.1128/mmbr.00046-12.

19. Rodriguez-Saona LE, MM. Giusti, W.D. Robert and W.E. Ronald. Development and process optimization of red radish concentration extract as potential natural red colorant. J Food Process Preserv. 2001; 25: 165-182.

20. Giguère, S, Lee EA, Guldbech KM, Berghaus LJ. In vitro synergy, pharmacodynamics, and postantibiotic effect of 11 antimicrobial agents against Rhodococcus equi. Vet Microbiol. 2012; 160(1-2): 207-213.

21. Li, X. H. \& Lee, J. H. Antibiofilm agents: a new perspective for antimicrobial strategy. J Microbiol; 10.1007/s12275-017-7274-x (2017).

\section{Tables}

Table 1 Absorbances of total violacein produced by C. violaceum CV026 


\begin{tabular}{ccc}
\hline Isolate & CV026 + Extract & CV026 + Extract + proteinase-K $+95^{\circ} \mathrm{C}$ \\
\hline $1 \mathrm{AC}$ & $0.9770 \pm 0.0092$ & $1.0310 \pm 0.0035$ \\
\hline $11 \mathrm{AC}$ & $1.0460 \pm 0.0029$ & $1.0260 \pm 0.0069$ \\
\hline $14 \mathrm{PM}$ & $0.8050 \pm 0.046$ & $1.0300 \pm 0.0029$ \\
\hline $15 \mathrm{PM}$ & $0.8565 \pm 0.0020$ & $0.7505 \pm 0.0234$ \\
\hline $16 \mathrm{PM}$ & $0.8625 \pm 0.0026$ & $1.1090 \pm 0.0012$ \\
\hline $18 \mathrm{PM}$ & $0.9190 \pm 0.0058$ & $1.1320 \pm 0.0035$ \\
\hline 20PM & $1.1760 \pm 0.0003$ & $0.8650 \pm 0.0115$ \\
\hline CW01 & $1.1230 \pm 0.0012$ & $1.1845 \pm 0.0032$ \\
\hline CW17 & $0.6945 \pm 0.0430$ & $0.8865 \pm 0.0009$ \\
\hline TB12 & $1.1690 \pm 0.0018$ & $1.0945 \pm 0.0141$ \\
\hline Control & $1.18515 \pm 0.0031$ & 0.0046 \\
\hline
\end{tabular}

CV026 = C. violaceum CV026

Table 2 Antibiofilm activity of actinobacteria crude extracts against pathogenic biofilm associated bacteria 


\begin{tabular}{|c|c|c|c|c|c|c|c|c|c|c|c|c|}
\hline \multirow[t]{2}{*}{ Pathogen } & \multirow{2}{*}{$\begin{array}{c}\text { Antibiofilm } \\
\text { Activity }\end{array}$} & \multirow[t]{2}{*}{ Crude Extract (\%) } & \multicolumn{10}{|c|}{$\%$ Activity } \\
\hline & & & $1 \mathrm{AC}$ & $11 \mathrm{AC}$ & $14 \mathrm{PM}$ & $15 \mathrm{PM}$ & $16 \mathrm{PM}$ & $18 \mathrm{PM}$ & $20 \mathrm{PM}$ & CW01 & CW17 & TB12 \\
\hline \multirow[t]{2}{*}{ SA } & & 5 & 65 & $87 *$ & 78 & 43 & 64 & 46 & 55 & 76 & 74 & 44 \\
\hline & & 10 & $90 *$ & $90^{*}$ & 79 & 66 & 75 & 74 & 76 & 77 & 75 & 62 \\
\hline \multirow[t]{2}{*}{$\mathrm{BC}$} & & 5 & $89 *$ & 85 & 76 & 78 & 84 & 57 & 86 & 84 & 85 & 81 \\
\hline & & 10 & $90 *$ & 87 & 76 & 83 & 87 & 69 & 88 & 87 & 85 & 84 \\
\hline \multirow[t]{2}{*}{$\mathrm{EF}$} & & 5 & 49 & 70 & 12 & 36 & 43 & 15 & 27 & 76 & $83^{*}$ & 33 \\
\hline & Inhibition & 10 & 82 & 71 & 34 & 71 & 77 & 40 & 50 & 83 & $84^{*}$ & 81 \\
\hline \multirow[t]{2}{*}{ VC } & & 5 & 93 & 89 & 90 & $\mathrm{x}$ & 93 & $\mathrm{x}$ & $\mathrm{X}$ & 9 & 92 & $94 *$ \\
\hline & & 10 & 76 & 79 & $84^{*}$ & $\mathrm{X}$ & 82 & $\mathrm{X}$ & $\mathrm{X}$ & 83 & 70 & 58 \\
\hline \multirow[t]{2}{*}{$\mathrm{ST}$} & & 5 & 76 & 83 & 84 & 80 & 81 & 81 & $85 *$ & 80 & 81 & 81 \\
\hline & & 10 & 56 & 63 & 50 & 54 & 27 & $76^{*}$ & 59 & 63 & 66 & 25 \\
\hline \multirow[t]{2}{*}{$\mathrm{PA}$} & & 5 & 29 & 70 & 49 & 38 & 50 & 39 & 37 & 47 & $54^{*}$ & 42 \\
\hline & & 10 & 83 & 82 & 86 & 91 & 85 & 81 & 89 & $93 *$ & 87 & 37 \\
\hline \multirow[t]{2}{*}{ SA } & & 5 & $62 *$ & 32 & 41 & 38 & 40 & 38 & 42 & 45 & 50 & 37 \\
\hline & & 10 & $77 *$ & 49 & 54 & 74 & 59 & 65 & 62 & 60 & 59 & 61 \\
\hline \multirow[t]{2}{*}{$\mathrm{BC}$} & & 5 & 61 & 67 & 64 & 67 & 65 & 67 & $75^{*}$ & 72 & 73 & 67 \\
\hline & & 10 & 84 & 80 & 78 & 68 & 84 & 75 & $85 *$ & 83 & 74 & 79 \\
\hline \multirow[t]{2}{*}{$\mathrm{EF}$} & & 5 & 43 & 44 & 50 & 47 & 47 & 45 & 46 & 50 & $52 *$ & 43 \\
\hline & Destruction & 10 & 58 & 63 & 55 & 70 & $72 *$ & 70 & 65 & 52 & 63 & 45 \\
\hline \multirow[t]{2}{*}{ VC } & & 5 & - & 52 & - & $\mathrm{X}$ & 71 & $\mathrm{X}$ & $\mathrm{x}$ & $73 *$ & 71 & 70 \\
\hline & & 10 & 11 & 48 & $62 *$ & $\mathrm{X}$ & 13 & $\mathrm{X}$ & $\mathrm{X}$ & 43 & 52 & 43 \\
\hline \multirow[t]{2}{*}{ ST } & & 5 & 57 & 43 & 54 & 34 & 29 & 58 & 51 & 66 & $73^{*}$ & 64 \\
\hline & & 10 & 56 & 20 & 72 & 54 & 47 & $82 *$ & 64 & 79 & 78 & 42 \\
\hline \multirow[t]{2}{*}{ PA } & & 5 & 11 & 53 & 29 & 54 & $63^{*}$ & 17 & 59 & 38 & 26 & 58 \\
\hline & & 10 & 43 & 45 & 41 & 57 & 42 & 50 & $55^{*}$ & 50 & $55^{*}$ & 50 \\
\hline
\end{tabular}

Staphylococcus aureus ATCC 29213; Bacillus cereus ATCC 14579; Enterococcus faecalis ATCC 33186, Vibrio cholerae, Salmonella typhimurium, Pseudomonas aeruginosa ATCC 27853.

*Highest activity, X Have antimicrobial activity, - No activity

\section{Figures}




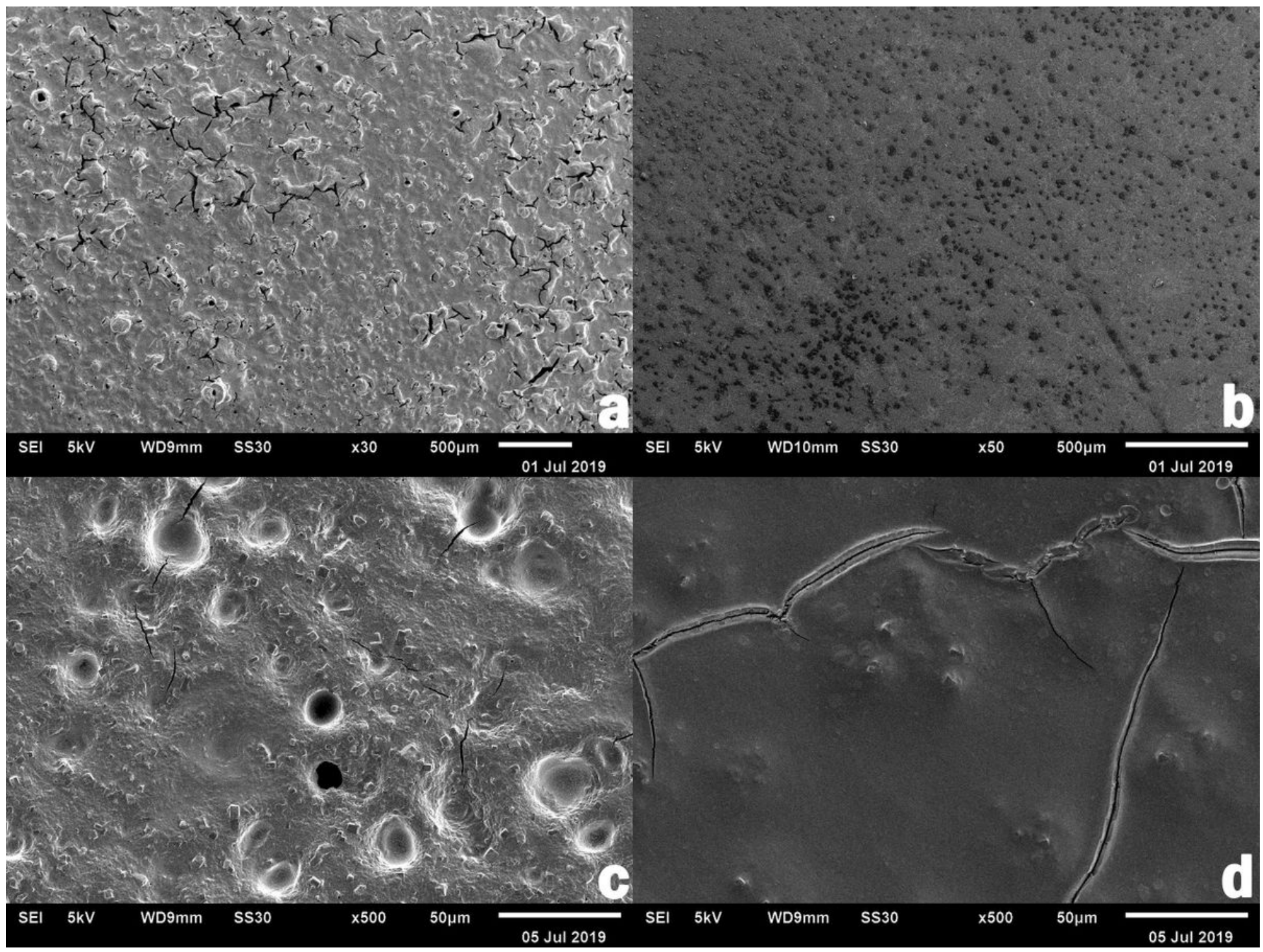

\section{Figure 1}

Biofilm of B. cereus ATCC 14579. (a) without treatment (b) with addition crude extract of 20PM isolate. Biofilm of S. typhimurium. (c) without treatment (d) with addition crude extract of CW01 isolate 